\title{
COPYRIGHT REFORM AND THE DUFFY BILL
}

COPYRIGHT legislation in this country and in England has been historically designed to further the development of literary and artistic works by conferring on the author, composer, or artist an exclusive property interest in his intellectual achievement and by affording such protection to this interest as will provide its owner a fair financial return. The beneficial effects which were thought to flow from the interest thus conferred were deemed to be ample justification for its inherently monopolistic character. ${ }^{1}$ But with the development of modern methods of marketing copyright material, together with the growth of radio and other media which have enormously increased the demand for such material, there has arisen an increasing dissatisfaction over the operation of existing copyright laws, and, since these laws have remained substantially unchanged since 1909,2 there has been recurring agitation for a thorough-going revision of the present copyright structure. $^{3}$

Impetus was afforded to revision in February 1934, when the President sent to the Senate the text of the International Convention of the Copyright Union as revised and signed at Rome in $1928,{ }^{5}$ and recommended that that body advise and consent to its ratification. The proper functioning of this convention, usually known as the Bern Convention for the Protection of Literary and Artistic Works, required some amendment to the existing copyright law, but the members of the Senate Committee on Foreign Rela-

1. U. S. Const. Art. I, §8, cl. 8; Copinger, LAw of Copyrigut (7th ed. 1936) 3; Hodrburg, Legal Rights of Perforaing Aatists (1934) c I; Miabchetti, Lay of the Stage, Screen, and Radio (1936) § 14.

2. 35 Stat. 1075 (1909), 17 U. S. C. $\$ \S 1-63$ (1934). Amendments were added by: 37 Stat. 488 (1912), 37 Stat. 724 (1913), 38 Stat. 311 (1914), 41 Stat. 369 (1919), 44 Stat. 818 (1926), 45 Stat. 713 (1928).

3. Hearings before Committee on Patents on Revision of Copyright Louss (House of Representatives), 74th Cong., 2nd Sess. (1936) passim; SEN. REP. No. 896, 74th Cong., 1st Sess. (1935) 1-2; Simpson, The Copyright Situation as Affecting Radio Broadcasting (1931) 9 N. Y. U. L. Q. REv. 180; Solberg, The Present Copjright Sitration (1930) 40 YALE L. J. 184.

4. 78 Cong. REc. 2768 (1934), made public as Executive Order, 78 Cosc. Rec. 9714 (1934).

5. Copinger, op. cit. supra note 1, 409-428; Register of Copyrights, Information Circulars, 4, 4A, 4B.

6. The necessity for local legislation to effectuate the terms of the treaty depends upon whether or not the treaty is self-executing. See Whitney v. Robertson, 124 U. S. 190, 194 (1888); Crandall, Treattes, Their Mlaming and Enroscensenit (2d ed. 1916) 161. A similar treaty for protection of industrial property was held not selfexecuting in Rousseau v. Brown, 21 App. D. C. 73 (1903). And see Crandaner, rupra, at 236; Hearings, op. cit. supra note 3, at 1094, 1375.

Several major changes were required. The present Section 15 requires that bools and periodicals entitled to copyright protection under the act which are in the English language must be printed from type set in the United States. The Bill permits copyright 
tions, to whom the matter was referred, decided that entrance into the convention ought to be preceded by a more exhaustive examination of the entire copyright system for the purpose of adapting it to modern conditions. ${ }^{7}$ During the months prior to the opening of the Seventy-fourth Congress in January 1935, an interdepartmental committee composed of representatives of the Departments of State and Commerce and the Copyright office of the Library of Congress held hearings for all those interested in the copyright field, with a view toward drafting the desired legislation. ${ }^{8}$ Finally, in April $1935,{ }^{9}$ Senator F. Ryan Duffy of Wisconsin introduced his first copyright bill. ${ }^{10}$ This was later withdrawn ${ }^{11}$ and another substituted ${ }^{12}$ with minor changes. The latter bill was passed by the Senate ${ }^{13}$ but was not reported out by the House Committee on Patents before the close of the Seventyfourth Congress. An identical bill has been introduced in the Senate of the new Congress, ${ }^{14}$ but no action has as yet been taken by the Committee on Patents to which it was referred.

The Duffy Bill, as it now stands, represents several substantial changes in our present copyright law. In dealing with both the domestic and international situation, it purports to strike a fair balance between advantages and disadvantages to the producers and consumers of copyrighted material. Of primary advantage to producer organizations are the provisions of the Bill relating to membership in the Bern Convention. Although originally desired by both the creators and consumers of literary and artistic works, ${ }^{15}$ adherence to the Convention is now considered of value primarily to the former

for foreigners without American printing in order to satisfy the Bern Convention requirements, but requires it for ultimate distribution. S.7, 75th Cong., 1st Sess. (1937) $\S 11$. Other changes enacted for a similar reason concern divisibility of copyright and copyright without formality. See p. 435 , infra. For discussions of these changes, sec Hearings, op. cit. supra note 3, at 469, 485, 1104.

An additional source of possible conflict may be found in the concept of moral rights or rights against mutilation of a copyright work which pertains abroad. See COPINGER, op. cit. stipra note 1 , at 414 .

It has been strenuously argued that if the treaty is not self-executing the Bill fails in its purpose because the changes do not comply with the requirements of the Convention. See Hearings, supra, 1078 et seq.

7. Sen. Rep. No. 896, 74th Cong., 1st Sess. (1935) 2.

8. SEN. Exec. Rep. No. 4, 74th Cong., 1st Sess. (1935) 4-5.

9. 79 Cong. REc. 4727 (1935).

10. S. 2465, 74th Cong., 1st Sess. (1935).

11. 79 CoNG. ReC. 9257 (1935).

12. S. 3047, 74th Cong., 1st Sess. (1935).

13. 79 Cong. ReC. 12615 (1935).

14. S.7, 75th Cong., 1st Sess. (1937). The Senate Committee on Foreign Relations approved on Nov. 26, 1937, the proposal for a treaty which would allow the United States to enter the Union as revised in Rome in 1928. See 132 Puntisners WEEKLY (1937) 2127.

15. Hearings, op. cit. sitpra note 3 , at 399 . 
group. .6 $^{16}$ Membership by the United States will obtain for our authors and composers the same rights under foreign law that nationals of the forty-six signatory powers have in their own countries. ${ }^{17}$ In addition, both the Convention ${ }^{18}$ and the Duffy $\mathrm{Bill}^{19}$ provide for automatic copyright, or copyright without formality, by which the mere fact of creation of a copyrightable work will constitute a copyright in every foreign country adhering to the Union. Although the bill would seem to discriminate against our own nationals, who do not obtain the advantages of copyright without formality, reciprocal advantages of automatic copyright abroad would be of great value to American producers of copyrighted material, since their work is now frequently pirated in foreign countries because of the severe limitations on formal copyright resulting from distance and language difficulties. ${ }^{30}$ Of equal value to American authors and song writers are the provisions of the Duffy Bill relating to divisibility of copyright. ${ }^{21}$ Whereas the present lav makes no specific provision for an assignment of only part of the rights and privileges inhering in a copyright ${ }^{22}$ and leaves the efficacy of partial assignments to the more uncertain rules of case law, ${ }^{23}$ the proposed bill specifically provides that such interests may be granted away. Not only are the distinct rights in a copyrighted work separately alienable, but the bill extends the principle of divisibility even further and provides that assignment of copyrights may, at the owners' discretion, be limited to a part of the entire term and to specific localities.

In spite of these concessions the creators of copyrightable works have placed themselves on record as being almost unanimously opposed to the Duffy Bill. ${ }^{24}$ So intense is their opposition to the Bill as a whole that even mem-

16. SEN. REP. No. 896, 74th Cong., 1st Sess. (1935) 3; Dufiy, Intemational Copyright (1937) 8 AIR L. R. 213; Solberg, Copyright Low Reform (1925) 35 Y ALE L. J. 48; Solberg, The Intemational Copyright Union (1926) 36 YALE L. J. 6S; Solberg, The Present Copyright Situation (1930) 40 YALE L. J. 184. See also speech by Senator Duffy before the Section of International and Comparative Law of the American Bar Association on May 5, 1937, reprinted 81 Cosg. REc. 5547 (1937).

17. Art 4(1).

18. Art $4(2)$.

19. $\S 6$.

20. See Duffy, Intemational Copyright (1937) 8 AIR L. REv. 213, 216; Hearings, op. cit. supra note 3, at 239. See statement by Mfargaret Mfitchell concerning the pirating in Holland of "Gone With the Wind" 132 Publismers Wencry (1937) 2282.

21. $\$ 24$.

22. 35 Stat. 1084 (1909), 17 U. S. C. $\$ 42$ (1934).

23. See Fitch v. Young, 230 Fed. 743 (S. D. N. Y. 1916), aff'd, 239 Fed. 1021 (C. C. A. 2nd, 1917). Compare Standard Mfusic Roll Co. v. F. A. Mrills, Inc, 241 Fed. 360 (C. C. A. 3rd, 1917), and Coca-Cola Co. v. State, 225 S. W. 791 (Tex. Civ. App. 1920), with Ford v. Chas. E. Blaney Amusement Co., 148 Fed. 642 (S. D. N.Y. 1906) and M. Witmark \& Sons v. Pastime Amusement Co., 298 Fed. 470 (E.D.S. C. 1924).

24. For an attack on almost every provision of the Bill, see brief filed by Mr. Nathan Burkan in behalf of the American Society for Composers, Authors and Pub- 
bership in the International Union, previously advocated, is now attacked as undesirable. It is argued that due to present racial restrictions in some foreign countries, coupled with limitations on exchange in many more, the American composers and authors have very little to gain by United States adherence to the Bern Convention. ${ }^{25}$ Actually, however, other reasons motivate this attack upon the Convention, for it is clear that the sensible way to cope with racial and exchange restrictions is by treaty and negotiation $;^{20}$ aloofness cannot better the position of the American artist abroad and may give only additional incentive to foreign infringement and retaliatory legislation. Behind the almost unanimous producer opposition to membership in the convention is a more profound antagonism to the Duffy Bill on the ground that it is an "infringer's bill." 27 Irrespective of the truth of this contention, it is undeniable that a number of the provisions of the Bill are concessions to user organizations. ${ }^{28}$ Most important of these concessions, and consequently most provocative of vitrolic criticism, ${ }^{29}$ is the elimination of the minimum damage clause ${ }^{30}$ which has long been recognized as the mainstay of copyright protection.

Provision for minimum damages in copyright legislation is not merely an experimental device first conceived of in the present act in the United States. Actually, it is older than copyright law itself, for the Stationers' Company, holder of a monopoly on printed matter by letters patent from the king, incorporated in its by-laws, in 1681, a provision that any member who printed a book previously registered with the company by another member was to forfeit to the organization the sum of twelve pence for each unauthorized copy printed. ${ }^{31}$ But the regulation of the Stationers' Company was of

lishers, Hearings, op. cit. supra note 3, at 1093 et seq. And see briefs submitted by the various industries affected by the Bill. Hearings, supra, at 1402 et seq.

25. Id., at $238,242$.

26. Id., at 263.

27. See e.g., Hearings, op. cit. supra note 3, at 1087.

28. Among the provisions of the Bill which have been attacked by copyright owners are: $\S 17(\mathrm{~g})(1)$ (exemption of performances by charitable institutions); $\S 17(\mathrm{~g})$ (2) (exemption of performances by wired radio); $\$ 17(\mathrm{~g})(4)$ (exemption of incidental infringement in current event performances); $\$ 3$ (extension of compulsory licensing to phonograph recorders). These and many other provisions of the Bill are fully discussed and criticised in briefs submitted in behalf of ASCAP. See Hearings, op. cit. supra note 3 , at $102-139$; 1102-1122.

29. See Hearings, op. cit. sitpra note 3 , at $115,1106,1187$. In his testimony before the committee, Sidney M. Kaye, Attorney for the National Association of Broadcasters advanced the proposition that "the opposition to the Bern Convention on the part of ASCAP is another smokescreen, and that their real ground for opposition to this Bill remains the elimination of the onerous minimum damage clause." Hearings, supra, at 399.

30. The minimum damage provision appears in the present Copyright Act as 35 Stat. 1081 (1909), 17 U. S. C. §25(b) (1934).

31. Birrell, The Law and History of Copyright in Books (1899) 79. 
course not binding on non-members, and, with the expiration of the monopoly, country printers and unscrupulous booksellers combined to reprint and sell pirated editions of the works of the more popular authors. Due to the operation of the previous monopoly, the authors had been forced to sell their rights to the members of the company, who now found these rights virtually valueless, since the actual sales of pirated editions were difficult to discover and real damages almost impossible to prove. ${ }^{32}$ The booksellers of the company, therefore, clamored for assistance from Parliament, and, as a result of their frequent petitions, the so-called Statute of Anne, ${ }^{33}$ the first copyright law, was passed in 1709 . It provided for a registration procedure similar to that in modern statutes, but of most significance to the booksellers were the provisions that infringing copies were to be turned over to the owner of the copyright to destroy, and the defendant required to forfeit one penny for each sheet found in his custody, the proceeds to be divided equally between the crown and the plaintiff in the action.

In this country, twelve of the original thirteen colonies passed copyright legislation with the form and phraseology of the Statute of Anne as a model, ${ }^{34}$ but with the adoption of the Federal Constitution the necessity for state legislation disappeared..$^{35}$ The first federal copyright law was enacted in $1790,{ }^{36}$ and this, too, was based on its English predecessor. The statutory damage clause of this act ${ }^{37}$ provided that for every infringement of a copyrighted map, chart, or book, the infringing copies should be forfeited and destroyed and the infringer required to pay fifty cents per sheet, one half of the sum recovered going to the government and the other half to the author. The first general revision of this act ${ }^{38}$ increased the forfeiture to one dollar per sheet for the infringement of prints, cuts, engravings, maps, charts and musical compositions, but maintained the old rate as to books.

The outstanding characteristic of this early copyright legislation relating to statutory damages was that the statutes specified a fixed sum to be forfeited for each infringement and consequently foreclosed the possibility of a civil action for provable loss. ${ }^{39}$ Although damage actions had earlier been permitted by statute for unauthorized publication of hitherto unpublished manuscripts, ${ }^{40}$ the first real damage clause for infringement of copy-

32. See id., at 90; Millar v. Taylor, 4 Burr. 2303, 2317 (K. B. 1769).

33. 8 Anne c. 19 (1709). See Tonson v. Collins, 1 Blacke W. 321 (1761).

34. For a collection of these statutes, see Solberg, Copyrigar Exacturewits op the United States (1906) 1-30.

35. U. S. Const. ARr. I, $\$ 8$, cl. 8. But see Solberg, op. cit. sapro note 34 , at 105-112, for later state statutes designed to protect property interests in uncopyrighted works.

36. 1 Stat. 124 (1790).

37. Id., $\S 2$.

38. 4 StAт. 436 (1831).

39. Wheaton v. Peters, 8 Pet. 591 (U.S. 1834); Banlss v. Manchester, 128 U. S. 244 (1888) ; Bobbs-Merrill Co. v. Straus, 210 U. S. 339 (1908).

40. E.g., 1 Stat. 125 (1790). 
righted material appeared in the amendments to the copyright law of $1856,{ }^{41}$ which provided that damages might be obtained for infringement of a dramatic composition by public performance or representation. And even here the act did not provide for simple common law damages but introduced a statutory minimum, $\$ 100$ for the first infringement and $\$ 50$ for each subsequent one. In the general revision of $1870,{ }^{42}$ however, the civil action for proven damages was extended to infringements of copyrighted books; simple common law damage principles, without any statutory limitations, were to be applied. The provisions of previous acts relating to infringement of the copyright of musical or dramatic compositions remained unchanged by the revision.

In 1909, Congress once again overhauled the system of copyright laws and provided for the minimum damage clause as we know it today. ${ }^{43}$ Section 25 of the statute, which applies equally to all infringements, ${ }^{44}$ provides the owner of the copyright with alternative remedies. He may enjoin a threatened infringement of his rights; he may maintain a civil action for the recovery of provable damages and profits made by the infringer from his wrongftil act; or he may seek to recover "in lieu of actual damages and profits" an award to be determined by the court's discretion, but which shall in no case be less than $\$ 250$ nor more than $\$ 5,000$.45 Within these limits common law principles of damage may apply, although here, too, the cottrt's discretion is guided by schedules evaluating the different types of infringement. ${ }^{40}$ While there was some slight hesitancy in the earliest cases ${ }^{47}$ arising

41. 11 Stat. 138 (1856); cf. Brady v. Daly, 175 U. S. 148 (1899). The provisions of the act were extended to public performance of a musical composition. 29 STat. 481 (1897).

42. 16 Stat. 212 (1870). For a more detailed historical survey, see Solberg, Copyright Law Reform (1925) 35 YALE L. J. 48.

43. The act was amended in 1912 to protect motion picture rights." 37 STAт. 489.

44. The unauthorized newspaper reproduction of a copyrighted photograph, however, gives a minimum damage of only $\$ 50$ and a maximum of $\$ 200$; innocent infringcment of non-dramatic or undramatized work by means of motion pictures has a maximum of $\$ 100$ and no minimum.

45. Whether actual or statutory damages should be awarded is determined by the trial court. Fargo Mercantile Co. v. Brechet \& Richter Co., 295 Fed. 823 (C. C. A. 8 th, 1924). But where both are readily ascertainable the court should choose actual damages as the appropriate remedy. Atlantic Monthly Co. v. Post Publishing Co., 27 F. (2d) 556 (D. Mass. 1928). But see DeWolf, An Outline of Copyright Law (1925) 165.

46. The function of these guides within the fixed limits is explained in JewellLaSalle Realty Co. v. Buck et al., 283 U. S. 202 (1931); Waterson, Berlin \& Snyder Co. v. Tollefson, 253 Fed. 859 (S. D. Cal. 1918).

47. Woodman v. Lydiard-Peterson Co., 192 Fed. 67 (S. D. Minn. 1912); Mills, Inc. v. Standard Music Roll Co., 223 Fed. 849 (D. N. J. 1915), aff'd, 241 Fed. 360 (C. C. A. 3rd, 1917) ; Alfred Decker Cohn Co, v. Etchison Hat Co., 225 Fed. 135 (E. D. Va. 1915) ; see Westermann Co. v. Dispatch Printing Co., 233 Fed. 609, 611 (C. C. A. 6th, 1916). 
under Section 25, the courts have almost unanimously followed the decision of the Supreme Court in L. A. Westernanan Co. v. Dispatch Printing Co., 4 and have enforced the minimum damage provisions irrespective of whether any actual damage has been shown. And though the amount of the award will depend upon the facts of each case, the courts have recognized that their discretion is limited by the minimum and maximum provisions of the statute. ${ }^{49}$

The ultimate recognition of the principle of statutory damages outlined above was largely predicated upon the historic argument that the awards as determined by the statutes were not unreasonable, since they seldom compensated the copyright owner for his expenses in curtailing infringement; ${ }^{\text {to }}$ but an appraisal of the present utility of the clause must necessarily comprehend an examination of its operation upon the existing copyright scene. Preliminary to such an examination it is important to understand the various types of copyright interests which the proprietor is forced to protect. There are two primary rights in copyrighted books, plays, or musical compositions, the sale of which must constitute the major sources of revenue available to the copyright owner. Of these two, the right to publish or reproduce the subject of the copyright was originally the most substantial. The second, the right of public performance, was of some value to holders of copyrights in dramatic compositions, since any unlicensed public performance constituted an infringement under the Act of $1909 ; 01$ but it was of no practical worth to the composers of music since they possessed solely the rights to public performance for profit, ${ }^{52}$ these being thought to include only performances for which an admission fee was charged.53 Consequently enter-

48. 249 U. S. 100 (1919).

49. Berlin v. Daigle, 31 F. (2d) 832 (C. C. A. 5th, 1929); Hendricks Co. v. Thomas Publishing Co., 242 Fed. 37 (C. C. A. 2nd, 1917) ; Witmark \& Sons v. Calloway, 22 F. (2d) 412 (E.D. Tenn. 1927). The trial court has complete discretion and if within the statutory limits it will not be reviewed by the appellate court. Douglas v. Cunningham, 294 U. S. 207 (1935) ; Hartfield v. Peterson, 91 F. (2d) 993 (C.C.A. 2nd, 1937). Contra: Turner \& Dahnken v. Crowley, 252 Fed. 749 (C.C.A. 9th, 1918).

Where the statutory minimum appeared unfair under the circumstances, however, some courts have refused to award counsel fees [Fisher v. Dillingham, 298 Fed. 145 (S. D. N. Y. 1924)], or have made them unusually small [Cravens v. Retail Credit Men's Ass'n, 26 F. (2d) 833 (M. D. Tenn. 1924)]. But see Witmarls \& Sons v. Calloway, 22 F. (2d) 412, 415 (E. D. Tenn. 1927).

50. See Douglas v. Cunningham, 294 U. S. 207, 209 (1935); BrRrels, of. cit. suspra note 31, at c. III; WeIL, AMrerican Copyright LAw (1917) 476.

51. 35 Stat. 1081 (1909), 17 U. S. C. \$1(d) 1934.

52." Id., \&1(e).

53. John Church Co. v. Hilliard Hotel Co., 221 Fed. 229 (C.C.A. 2nd, 1915); Herbert $\nabla$. The Shanley Co., 229 Fed. 340 (C.C.A. 2nd, 1916); see Simpson, The Copyright Situation as Affecting Radio Broadcasting (1931) 9 N. Y. U. I. Q. REv. $180,188$. 
tainments in hotels, restaurants, cabarets, night clubs, and roadhouses, which were considered merely incidental to the operation of the premises, were exempt from any copyright limitations. The right of the composer in the public performance of his music took on a new importance, however, in 1917, when in the case of Herbert v. The Shanley Co., ${ }^{54}$ the Supreme Court extended the scope of copyright protection by holding that music played to attract patronage constituted a public performance for profit within the meaning of the Copyright Act, even though the public did not pay directly for the privilege of hearing it.55 Moreover, this extension was soon followed by another, for in Buck v. Jezeell-LaSalle Realty Co., 50 the Supreme Court promulgated the doctrine of second user, holding that, when a radio broadcast or phonograph recording ${ }^{57}$ is heard publicly and for profit under the broad definition of the Herbert case, the retransmission amounts to a second performance, actionable under the statute. ${ }^{.8}$ As a result of these decisions, the performing rights possessed by the composer of a copyrighted piece of music became as important a source of revenue as the publication rights formerly had been.

The distinction between the two types of rights in copyrighted works is of importance chiefly because it forms the basis of two somewhat divergent methods of protecting copyright interests. When the author of a book or composer of a song wishes a financial return for the publication or reproduction rights in his product, he will negotiate with various publishers, motion picture companies, and possibly phonograph recorders ${ }^{\text {to }}$ until an arrange-

54. 242 U. S. 591 (1917).

55. The case of Herbert v. The Shanley Co., 229 Fed. 340 (C. C. A. 2nd, 1916) involved performance of copyrighted music in restaurants and hotels. It was followed by several other cases which extended the doctrine to music played in motion picture theatres [Harms v. Cohen, 279 Fed. 276 (E. D. Pa. 1922); Witmark \& Sons v. Pastime Amusement Co., 298 Fed. 470 (E. D. S. C. 1924), affd, 2 F. (2d) 1020 (C. C. A. 4th, 1934)], and over the radio [Witmark \& Sons v. Bamberger \& Co., 291 Fed. 776 (D. N. J. 1923) ; Remick \& Co. v. American Auto Accessories Co., 5 F. (2d) 411 (C. C. A. 6th, 1925)]. See Simpson, sitpra note 53, at 189, 190. But see (1936) 7 Ais L. REv. 115.

56. 283 U. S. 191 (1931); Simpson, supra note 53, at 192; Comments (1931) 20 Calif. L. Rev. 77; (1932) 12 B. U. L. Rev. 243 ; (1931) 26 ILl. L. Rev. 443; cf. Performing Right Soc. Ltd. v. Hammond's Bradford Brewery Co. Ltd., 176 L. T. 312 (1933), (1934) 47 HaRv. L. REv. 703.

57. Although the case actually involved only a radio broadcast, the decision states that phonograph recordings constitute a second performance and, if unauthorized, an infringement. See Buck v. Jewell-LaSalle Realty Co., 283 U. S. 191, 198, 201 (1931).

58. The decision in the LaSalle case may, however, be limited to the precise fact situation in that case. The radio station broadcasting the song was likewise unlicensed, and the Court pointed out that it was not deciding the case in which the original performance was authorized by the copyright owner. See Buck v. Jewell-LaSalle Realty Co, 283 U. S. 191, 199, n. 5; cf. Buck v. Debaum, 40 F. (2d) 734 (S. D. Cal. 1929).

59. Negotiation with phonograph recorders is limited by $\$ 1(\mathrm{e})$ of the Copyright Act, which provides that upon granting authorization for a mechanical reproduction of a copyrighted work, the copyright owner is limited to a royalty of two cents on repro- 
ment is reached which is satisfactory to both parties concerned. In the case of infringement by some competing agency, the original owner of the copyright, or his licensee or vendee, will personally bring an action against the infringer. In this situation the identity of the defendant together with the fact of infringement will usually be readily ascertainable, for the printed copies or reproductions afford tangible evidence of the violations. In some instances, since it may even be possible to establish the amount of profits made by the infringer, the plaintiff need only rely on his statutory right to maintain a civil action for damages. In the more usual case, however, the damages suffered by the owner of the copyright will be incapable of legal proof, and where a book is reprinted in a current serial, or a popular piece of music prematurely recorded by a phonograph company, the author or composer may often have to rely entirely upon his right to collect a statutory award under Section 25 of the Copyright Act.

An interesting example of the operation of the minimum damage provision in this connection is furnished by the motion picture industry. Although the copyright situation in this particular field is somewhat complicated by the fact that motion picture producers are both consumers and creators of copyright material, the system of marketing films which has been developed in that industry is peculiarly dependent upon the effective operation of the copyright law. Each exhibitor is licensed by the distributors to show certain films a given number of times on specific dates. In the event that one of the exhibitors refuses to comply with the terms of his license, as 6.9 ., by retaining a particular film beyond the specified time, the distributor's only practical remedy is an action brought under the statutory damage provision of Section $25^{60}$ If he merely refuses to send further films to the infringing exhibitor, the latter may obtain additional films from a competing distributor, who cannot refuse him for fear of prosecution under the Sherman AntiTrust Act. ${ }^{\text {.1 }}$ The use of an injunction against the infringer would be equally unavailing, for the infringement would be completed long before the injunction could be obtained. Nor would the distributor obtain the necessary redress in a contract action for provable damages against the exhibitor, since the damage results not so much from the loss of the license fee as in the disruption of distribution schedules, the disregard of the licensing system,

ductions by other companies. The negotiation is thus limited to the value of the right to be first in the market with a given musical number, since other rights in the mechanical production are worth no more than two cents per record.

60. Vitagraph, Inc v. Grobaski, 46 F. (2d) 813 (WV. D. Afich. 1931); Tifiany Productions, Inc v. Dewing, 50 F. (2d) 911 (D. Mfd. 1931), (1931) 31 Coz. L. REv. 1187; cf. Pathe Exchange, Inc. v. Dalke, 49 F. (2d) 161 (C. C. A. 4th, 1931) ; AfetroGoldwyn-Mlayer Distributing Corp. v. Bijou Theatre Co., Inc, 59 F. (2d) 70 (C.C.A. 1st, 1932), rev'g, 50 F. (2d) 908 (D. Mass. 1931), (1931) 45 HAnv. L. Rev. 380.

61. 26 STAт. 209 (1890), 15 U. S. C. $\$ \S 1-7$ (1934); cf. United States r. First National Pictures, 282 U. S. 44 (1930); Paramount-Famous Lashy Corp. v. United States, 282 U. S. 30 (1930). 
the violation of priority of exhibition contracted for by other exhibitors, the possibility of a "dark theater" for subsequent exhibition because of the delay in returning a print, and, finally, the expense of the vigil necessary to detect and follow up such infringements. ${ }^{62}$ An action for the recovery of statutory damages, however, is subject to none of the defects which characterize the other remedies open to the distributor. Not only does it afford a summary method of obtaining reasonable retribution, but it acts as an effective deterrent to further violation of the distributor's marketing system, since the exhibitor will rarely persist in infringing if he knows that he will be liable for at least $\$ 250$ for each offense.

Although a statutory damage provision may often be a necessary incident of the protection of publication and reproduction rights in a copyrighted article, it is indispensable to adequate enforcement of performing rights in a musical composition. Protection of these rights is subject to practical limitations which have made enforcement difficult and at times impossible. ${ }^{03}$ In the first place, the intangible nature of the property interest represented by the performing right renders the possibility of proving actual infringements extremely hazardous, for the violation of proprietory interests by an orchestra or radio leaves no physical evidence of the appropriation. But, aside from difficulties of proof, the protection of performing rights is subject to a further handicap which arises from the multiplicity of consumer organizations, such as restaurants, night clubs, and roadhouses. With each one of these organizations constituting a potential source of infringement, an individual copyright owner would clearly be incapable of curtailing wholesale appropriation of his interest. If, therefore, the protection of performing rights were left solely to individual initiative the copyright proprietor might well be placed in the anomalous position of possessing a property interest in the right to perform under his copyright but of being unable to protect that interest sufficiently to realize any return upon it.

These hazards actually proved so real that there was virtually no enforcement of the law against infringers of the composer's performing rights in his music until 1914, ${ }^{64}$ when, under the leadership of Victor Herbert, the American Society of Composers, Authors, and Publishers, popularly known as ASCAP, was formed. ${ }^{05}$ The function of this Society was the promotion of collective marketing of performing rights in music in the United States. To it now belong the leading composers, authors and publishers of music, with a unanimity which approximates a monopoly of the field. ${ }^{66}$ The members assign to the Society all their non-dramatic performing rights for a

62. Hearings, op. cit. stipra note 3 , at 1187; see Sargay, The Case of the Copyright Law and the Motion Picture, 123 Motron Picture Herdid, May 23, 1936, p. 12.

63. Id., at 61,75 .

64. Id., at 8, 193; Shafter, Musical Copyright (1933) 221.

65. Shafter, id., at 222.

66. See (1934) 44 Yale L. J. 370, 373. 
period of five years, and it in turn licenses the various commercial users of music by means of a blanket license which allows the licensee unlimited use of all music in the ASCAP catalogue. ${ }^{07}$ The members are then ranked in several groups according to the relative popularity and demand for their work and upon this basis receive a proportionate share of the royalties collected from the licensees. ASCAP was hailed by both the creators and consumers of copyrighted music from its inception. os For the former, it successfully marketed performing rights and produced a financial return where previously there had been only wholesale infringement. For the latter, faced with the practical impossibility of securing sufficient licenses from individual composers, it provided a license sufficiently comprehensive to permit the extensive repertoire required by modern entertainment demands without the fear of infringement litigation.

In spite of the almost universal recognition of the need for an organization like ASCAP in the entertainment field, the fact that the Society virtually controls the right to conduct public musical performances for profit and that it has behind it the strong coercive powers of the minimum damage clause in Section 25 of the copyright law, has created considerable public animosity toward the organization. ${ }^{70}$ When the Society is informed through its extensive network of investigators ${ }^{71}$ throughout the country that some unlicensed theatre or cafe or hotel is using copyrighted music, it writes a letter informing the proprietor that he is violating the law and suggesting that he take out a license. The relevant sections of the copyright law are quoted, the leading cases cited, and the definition of "performance for profit" as haid down by the Supreme Court in Herbert v. The Shanley Co., reported in full. If there is no response, additional letters in much the same tone follow, with perhaps more emphasis on the possibility of a suit under Section 25. Finally, if the proprietor persists in disregarding these warnings, suit is brought for infringement. ${ }^{72}$ Realizing that under the minimum damage provision there can be no defense to this action, however, the proprietor vill usually capitulate before trial and obtain a license from the Society. ${ }^{73}$ But even when judgment has been finally entered, the Society very rarely attempts to recover upon it, and generally compromises for the cost of a license to the infringer from the time the infringement was first discovered plus the expenses of the investigation and suit. ${ }^{74}$ Thus, although the minimum damage clause is seldom employed to recover substantial sums from unauthorized users of

67. Hearings, op. cit. supra note 3 , at 19.

68. SHAFTER, op. cit. supra note 64 , at 222 .

69. Hearings, op. cit. supra note 3 , at 26,596 .

70. Id., at 481 .

71. SHAFTER, op. cit. supra note 64 , at 224-225.

72. Hearings, op. cit. supra note 3 , at 816-\$29.

73. Id., at 772 .

74. Id., at 233, 772. In the twenty-two years of its existence up to 1936, ASCAP has actually collected only $\$ 8,800$ on minimum damage judgments. Id., at 27 . 
copyrighted music, it does operate to compal compliance with the demands of the Society for licensing.

In addition to these objections to its coercive power, ASCAP is open to the usual attacks made upon monopolistic enterprises. ${ }^{75}$ Indeed, the very effectiveness of the minimum damage provision, as it has been utilized by the Society, strongly suggests that unrestrained application of the clause may give rise to abuse of the copyright privileges which it was designed to protect. In the first place, the methods adopted by ASCAP to secure licensees probably have added to the cost of conducting public entertainment, and this is probably passed along to the public. Furthermore, because of its almost exclusive operation in the field of performing rights, ASCAP is in an extremely strong bargaining position with respect to its individual licensees. ${ }^{70}$ In conducting negotiations relating to the formation of license agreements, the Society, unrestrained by the healthy moderative effect of competitive bidding, is free to exact whatever terms it thinks reasonable, and if the prospective licensee wishes to continue to use music, he must accede to these terms or subject himself to the risk of incurring a heavy statutory liability. Although this inequality of bargaining power is probably subject to an exception in the case of the Society's more powerful customers, notably the radio, it is particularly offensive to the small consumer of music for profit who can rely only on the alleged benevolent attitude of the Society toward its various licensees. ${ }^{77}$

The extent of ASCAP's altruism can only be a matter of conjecture, but it is significant to note that although the Duffy Copyright Bill was designed as a comprehensive revision of the entire copyright law, the hearings on the Bill before the House Committee on Patents developed into an extensive attack upon, and defence of, the Society. The underlying hypothesis of the proponents of the Bill is roughly that in order to prevent copyright proprietors from exercising their monopolistic power in a manner subversive to the general welfare, it is necessary to weaken the various protective devices hitherto afforded by the copyright statute. The authors of the Bill have attempted to attain this objective in two significant ways. First, the Bill provides that in an action for the recovery of profits made by the defendant as a result of the infringement, the proprietor shall be permitted to recover all or only such part of these profits "as the court may decree to be just and proper,"78 whereas previously he was awarded all profits. ${ }^{70}$ Secondly, the Bill provides that where the proprietor seeks an award in lieu of damages, he shall be given merely " . . . such damages . . . as shall in the opinion of the court be sufficient to prevent their operation as a

75. Id., at 484 .

76. See note 60 supra.

77. Hearings, op. cit. supra note 3 , at 26 .

78. S. 7, 75th Cong., 1st Sess. (1937) $\$ 17$.

79. 35 Stat. 1081 (1909), 17 U. S. C. $\S 25$ (b) (1934). 
license to infringe, and as shall be just, proper, and adequate, in view of the circumstances of the case . . ." No minimum is set but the maximum possible award is raised from $\$ 5,000$ to $\$ 20,000$ for each infringement. ${ }^{80}$

The first of these two suggested amendments is based upon the supposition that in the case of a partial infringement of copyright privileges, the infringer ought not to be subjected to a liability determined by the total profits which he has derived from the completed work. But although the existing provision of the statute may occasionally result in inequitable awards, it has the double advantage of deterring infringement and of being comparatively simple to administer. The proposed amendment would seem to be deficient in both respects, for not only is it practically impossible to allocate that portion of the total profits which has been derived from the partial infringement, but the provision in its present form would operate as a virtual invitation to infringe. It is conceivable that an infringer might steal a short scene from a book or a play, or that a popular serial magazine might reproduce a whole story which would contribute ten percent to the length of the infringing publication and ninety percent to its commercial success. Since the copyright proprietor would probably be unable to prove the relationship between the infringement and the ultimate public demand for the publication as a whole, the infringer might find that he was in a better position financially after having defended an action for profits received than if he had refrained from the infringement and had secured a license preliminary to the publication.

Although the provisions of the Duffy Bill relating to the apportionment of profits are important in connection with civil actions for provable damages, the proposed elinination of the minimum damage provision is of far greater general significance, since the right to sue for statutory damages applies to the more usual situation where actual losses cannot be shown. During the hearings, emphasis was laid on the high license fees made possible by the statutory damage provision, and there was some support for the argument that these rates bear a direct relation to the amount of the minimum avard provided under the clause. ${ }^{81}$ As already indicated, however, in actual practice the amount realizable by a copyright proprietor from his copyright interest depends on a variety of circumstances which vary considerably according to the particular type of interest concerned. In the case of the license or sale of the publication or reproduction rights in a book, play, or musical composition, the determinative factor will usually be the demand that the author may arouse for his particular product. In short, the owner of the copyright will accept the highest of the various bids which he may receive from the numerous publishers, motion picture producers, and phonograph recorders to whom he may submit the copyrighted article.

80. See note 78 supra.

81. Hearings, op. cit. sipra note 3 , at 228 , et seq. 
It is only in connection with the marketing of performing rights in copyrighted music that competition fails to reduce excessive license fees, ${ }^{82}$ and even in this field it is doubtful whether fees are determined by the amount of the statutory award. ASCAP has developed an extraordinarily efficient method of curtailing infringement of its copyrights, and it is conceivable that the Society might raise its rates to a point which would force prospective licensees to run the risk of infringement litigation rather than submit to the license terms..$^{83}$ With so severe a penalty for infringement, it is, therefore, theoretically possible that the Society would set rates out of all proportion to the benefits obtained by licensees. This eventuality would be highly unlikely, however, since its effect would be abandonment of musical entertainment by the small consumers and consequent diminution of total returns to ASCAP. ASCAP's rates must be determined by an estimate of what the various types of licensees will pay for the benefits secured, and, although this approximation might well result in unjustifiably high rates, an examination of ASCAP'S license agreements and of its total annual return fails to disclose any arbitrary use of its monopolistic powers. ${ }^{84}$ In spite of the obvious emotional appeal of an attack on monopoly, the argument for abolishing the minimum damage clause on this ground is scarcely conclusive. The value of the statutory damage provision lies not so much in the fact that it affords injured copyright owners occasional redress for past infringements or a greater income from license fees, but rather in the fact that the threat of its application operates to deter potential infringements. To this extent, the clause may be considered coercive in character, but since it affords needed

82. This does not mean that ASCAP is the only performing rights society in the United States. There are several others which primarily control foreign music. Hcarings, op. cit. supra note 3 , at 475 . Some competition may take place between these societies, and between users seeking the music of composers who deal individually, but it is negligible. ASCAP controls virtually all American music that is in demand for constant performance. See note 63 supra.

83. See Hearings, op. cit. supra note 3 , at 988.

84. Some typical rates are:

For theatres:

800 seats or less, 10 cents a seat per year.

$800-1600$ seats, 15 cents a seat per year.

1600 or more seats, 20 cents a seat per year.

\section{For hotels:}

$\$ 40-\$ 2,800$ per year depending on size, number of public rooms using music, For radio: number of private receivers in bedrooms.

$\$ 3,239,181$ paid by all radio chains to ASCAP in 1936, the fee of each station being based on power of station, hours on air, and estimated population coverage.

See Hearings, op. cit. supra note 3, at 13, 14, 19, 106, 597. And see (1937) Ascap Journal 17, 24. For a comparison of the rates charged by ASCAP and the total receipts of its licensees, see Hearings, supra, at 1111. 
protection to contractual obligations and property interests, some such clause must be considered a necessary adjunct to a workable copyright law.

While the present combination of ASCAP and the minimum statutory damage clause do not appear to present the dangers and inequities sometimes charged against them, other disadvantages appear to result from certain defects inherent in the provision itself. The major objection of the large consumers of copyrighted works is not that the mininum damage clause makes for exorbitant license rates or that ASCAP exerts any coercive force on its licensees, but rather that the.Act imposes too severe a penalty for too broad a series of infractions. ${ }^{85}$ Since knowledge of the copyright or intention to infringe are immaterial ${ }^{80}$ under judicial interpretation ${ }^{87}$ of the Section, unavoidable infringement is punished equally with deliberate piracy of copyrighted music. ${ }^{88}$ For example, it is almost impossible to determine within a reasonable time whether or not an unpublished composition has been copyrighted and, if so, by whom. ${ }^{89}$ But the use of such music is equally actionable with that which is published. Furthermore, small orchestras, unaware of the intricacies of the law, are often not sufficiently discriminating in their choice of music. If they happen to infringe, it is the proprietor of the establishment who must pay the $\$ 250$ minimum, ${ }^{90}$ and although a program of

85. Hearings, op, cit. supra note 3 , at $373,401,407$.

86. Under $\$ 25(\mathrm{~b})$, however, "in the case of the infringement of an undramatized or non-dramatic work by means of motion pictures, where the infringer shall show that he was not aware that he was infringing and that such infringement could not have been reasonably foreseen, such damages shall not exceed the sum of $\$ 100$. . . ."

Furthermore there are no limitations of maximum damage under $\$ 25$ where actual notice has been served on the infringer. Turner \& Dahnken v. Crowley, 252 Fed. 749 (C. C. A. 9th, 1918) ; Sebring Pottery Co. v. Steubenville Pottery Co., 9 F. Supp. 383 (N. D. Ohio 1932).

Willfulness to infringe is also necessary to impose the criminal penalties of the Act 35 Stat. 1082 (1909), 17 U. S. C. $\$ 28$ (1934). Cf. United States v. Schmidt, 15 F. Supp. 804 (M. D. Pa. 1936); United States v. Mrarx Bros., N. Y. Times, Oct. 31, p. 1, col. 4. These two are apparently the only prosecutions under the criminal provisions of the Act.

87. Buck v. Jewell-LaSalle Realty Co., 283 U. S. 191 (1931); see Arsdur, Cogyright Law and Practice (1936) 685; Drone, The Lay of Property in Intellectual Productions (1879) 401, 403, 638; Wert, Azrerican Copyright Lav (1917) 401.

88. Actually, of course, where the infringement is unavoidable and the actual damage trifling, the court will confine itself to the minimum. See Warren v. White \& Wyckoff Mfg. Co., 39 F. (2d) 922, 923 (S. D. N. Y. 1930) ; Asrouz, op. cit. supro note 87, at 1136; (1937) 37 CoL. L. REv. 487.

89. 35 STAT. 1078 (1909), 17 U. S. C. \$11 (1934). See Hearings, op. cit. supro note 3 , at 1120 . For a discussion of the effect of automatic copyright on broadeasters, see id., at 467 .

90. Berlin v. Daigle, 26 F. (2d) 149 (E. D. La. 1928); Dreamland Ball Room v. Shapiro, Bernstein \& Co., 36 F. (2d) 354 (C. C. A. 7th, 1929) ; cf. Gross v. Van Dyls Gravure Co., 230 Fed. 412 (C.C. A. 2d, 1916); Harms v. Cohen, 279 Fed. 276 (E. D. Pa. 1922) ; Witmark \& Sons v. Pastime Amusement Co., 298 Fed. 470 (E. D. 
dance music broadcast from a hotel or restaurant is often submitted in aclvance, a last minute request may be substituted in spite of strict orders to the contrary - and an infringement occurs. ${ }^{21}$ Here, it is the broadcasters ${ }^{02}$ who must pay at least the minimum damage, possibly for each of the ultimate transmitting stations. ${ }^{.3}$ The larger chains employ listeners, familiar with copyrighted music, who are prepared to tune out the offending orchestra as soon as they detect an infringement, ${ }^{94}$ but the cost of such a service would be prohibitive for the smaller stations. Still more inequitable, it is charged, is the situation where a secondary user under the definition of the JewellLaSalle case may pick up through his radio a band playing copyrighted music without authorization from the owner. ${ }^{95} \mathrm{He}$, too, under the strict interpretation of the law, would be guilty of an infringement, and the courts would have no alternative but to award a judgment for $\$ 250$ against him in the event of suit for statutory damages. ${ }^{96}$ With some copyriglits owned by authors and others by publishers ${ }^{27}$ innocent infringement may be frequent. Furthermore, it is possible for members to leave ASCAP after their agreements have terminated, and, before notification may be given the licensees, much unauthorized music may have been played by persons acting in con1plete good faith. ${ }^{98}$ Yet each performance is the potential basis of a suit which must result in a judgment for at least $\$ 250$ : The possibility of obtaining

S. C. 1924), aff'd, 2 F. (2d) 1020 (C. C. A. 4th, 1924); Witmark \& Sons v. Calloway, 22 F. (2d) 412 (E. D. Tenn. 1927). But cf. Fromont v. Aeolian Co., 254 Fed. 592 (S. D.N. Y. 1918).

91. Hearings, op. cit. supra note 3 , at 416 .

92. Remick \& Co. v. General Electric Co., 16 F. (2d) 829 (S. D. N. Y. 1926).

93. Whether only the original transmitting station or all stations in the chain are liable for an infringement has apparently not yet been determined. For discussion of the problem, see ShAFTER, op. cit. supra note 64, at 259; Section 17 of the Duffy Bill places liability for infringements by broadcasting chains upon the transmitting station. See Hearings, op. cit. supra note 3, at 480, 1120 et seq.

94. Id., at 416.

95. Id., at 373. The possibility of a suit for such infringement is, of course, remote, but a very analogous situation arose in England where an unlicensed newsreel picture of a parade picked up the band performance of a copyrighted song, and the newsreel company was held liable for infringement. Hawkes \& Son, Ltd. v. Paramount Film Service, Ltd., [1934] 1 Ch. 593, (1934) 20 CoRN. L. Q. 145; (1934) 44 YALE L. J. 370. The Duffy Bill specifically exempts an infringer from liability for "the merely incidental and not reasonably avoidable inclusion of a copyrighted work in a motion picture or broadcast depicting or relating current events." $\$ 17(\mathrm{~g})(4)$. See Hcarings, op. cit. supra note 3 , at 1092 .

96. Cf. id., at 1135 .

97. Id., at 441.

98. The most notorious instance was the withdrawal of the Warner Brothers publishing houses from ASCAP before the termination of their contract. For the facts and discussion of the problems arising, see Hearings, op. cit. supra note 3 , at 372,474 ; Comment (1936) 7 ArR L. REv. 78. A compromise has been reached and the Warner Bros. have since returned to the Society. 
results of this character is enhanced by the physical limitations under which even ASCAP must work. No catalogue of songs is published, but licensees are furnished only with a list of the Society members whose songs are covered by the license. ${ }^{99}$

There seems to be little necessity for these harsh results, which have created a tremendous animosity toward composers and their protective organizations. Several states have passed prohibitive laws aimed directly at ASCAP. ${ }^{100}$ The Federal Government instituted an anti-trust suit against the Society which was not prosecuted to judgment, but which remains a threat. ${ }^{101}$ Courts have seized upon the merest technicalities to throw out suits brought under Section 25 as the only way to avoid the \$250 damage requirement. ${ }^{102}$ As a result, the copyright owner has received nothing because the statute would have given him too nuch.

The amendment to Section 25 suggested in the Duffy Bill effectively removes this source of irritation by deleting the minimum sum of $\$ 250$. Moreover, the proponents of the Bill strenuously contend that the elimination of this clause will in no way impair the efficacy of copyright protection as developed under the existing law. ${ }^{103}$ The provision is still a statutory damage -clause. It does not require proof of actual loss or damage. It merely leaves the amount of the award to the discretion of the court, which shall be guided by the two principles that the damages shall be " . . . just, proper, and adequate, in view of the circumstances of the case . . . " and that they shall be " . . sufficient to prevent their operation as a license to infringe ...." Although the first condition is too vague to satisfy the creators of copyright works, the second provides assurance that the interests of authors and composers are still paramount. All that the owner of a copyright will have to show in order to recover ample retribution for his loss is infringement and the amount of his license fees. The court will then presumably take into consideration the possibility that the infringement would never be discovered and will give an award sufficiently in excess of the normal license rate to prevent the potential infringer from running this risk. If the courts would uniformly enforce the measure of damages set out in the provision, the adoption of this amendment would have little or

99. Hearings, op. cit. supra note 3 , at 472 .

100. Such statutes have been passed by five states. Fla. Gen. Act and Resolutions (1937) c. 17807, p. 204; Mont. Laws (1937) c. 90; Neb. Sess. Laws (1937) c. 138; Tenn. Pub. Acts (1937) c. 212; Wash. Sess. Laws (1937) c. 218. And see Hcarings, op. cit. supra note 3 , at 1114 et seq.

101. N. Y. Times, Aug. 31, 1934, p. 15, col. 3. See Peaslee, The Effect of the Federal "Anti-Trust Laws" on Commerce in Patented and Copyrighted Arlicles (1915) 28 HaRv. L. Rev. 394. Cf. Harms v. Cohen, 279 Fed. 276 (E. D. Pa 1922); Witmarls \& Sons v. Pastime Amusement Co., 298 Fed. 470 (E. D. S. C. 1924), offd, 2 F. (2d) 1020 (C. C. A. 4th, 1924).

102. Hearings, op. cit. supra note 3 , at 766.

103. See id., at 375,481 . 
no deleterious effect upon ASCAP or any other copyright owner. Indeed, obviation of the harsh results arising from the existing law might prove of considerable benefit to the Society by improving its relations with user organizations. ${ }^{104}$

Actually, however, it is questionable whether the stringency of the provision is justified by the evils which it is designed to cure. Apparently the only valid objection to the operation of the existing copyright law is the charge that the minimum damage requirement results in harsh decisions in cases of unavoidable infringement. But these comparatively rare cases are likely to arise only in the marketing of performing rights in music, while the abolition of the minimum damage provision would apply to all types of copyright protection. The value of the present clause depends to a large extent upon the certainty of its application in all cases of infringement. By introducing an element of judicial discretion, this certainty will inevitably disappear. Rather than jeopardize the entire copyright system resting upon the protection afforded by the minimum damage clause, it would seem preferable to retain this clause in substantially its present form but to exempt specifically those instances in which the "infringer" could not reasonably have known that his act constituted an infringement. ${ }^{105}$ An amendment of this kind would obviate the difficulties encountered by radio and other users of copyright music ${ }^{106}$ and at the same time would afford ample protection to the creators of copyright works. In no way would it affect ASCAP's present system of copyright protection, for the letters sent to the various potential licensees would give them actual knowledge before infringements had taken place. Only in the case where knowledge of the infringement could not possibly be obtained would an infringer escape liability under this amendment, and in such cases there is little justification for imposing liability.

Walter L. Pforzheimer $\dagger$

104. See id., at 247.

105. Section 17 of the Duffy Bill exempts certain incidental and unavoidable infringements, but this provision applies only to news reels and broadcasts of current events.

For a discussion of the feasibility of government regulation of license fees, sce Hearings, op. cit. supra note 3 , at 244 .

106. If it is true that the existing minimum requirement of $\$ 250$ determines the rates which a copyright owner may charge, and if these rates are higher than the value of the license to the user, there would seem to be no objection to lowering this sum, provided that the reduced amount would be sufficiently high to operate as a deterrent to infringement. Indeed, a reduction of the minimum award has already been suggested. See Hearings, op. cit. sitpra note 3, at 246.

†Third year student, Yale School of Law. This Comment was written in collaboration with a member of the Editorial Board of the JourNal. 